\title{
Enhancing Effect of Sodium Chloride on in vitro Adsorption of Paraquat onto Activated Carbon
}

\author{
Seiki Tanada*1, Takeo Nakamura*1, Ma Xiaohong*1, \\ Toshikazu Higuchi*1, Tamotsu Miyoshi*2, Takamichi Tamura*2 \\ and Masahide Imaki*2 \\ ${ }^{* 1}$ Faculty of Pharmaceutical Sciences, Kinki University, Osaka \\ *2Department of Public Health, School of Medicine, The University of Tokushima, Tokushima
}

\section{Introduction}

The usefulness of activated carbon for the primary treatment of various poisonings caused by swallowing of drugs or poisons has been recognized ${ }^{1,2)}$. In acute poisoning, activated carbon has been administered for the inhibition of absorption of drugs or poisons in the digestive tract, and its efficacy has been reported ${ }^{3,4)}$.

Paraquat has been widely used as a superior herbicide and is unlikely to produce serious problems when properly used ${ }^{5,6)}$. In Japan, however, many people have died through accidental, suicidal or homicidal ingestion of paraquat. The mortality from paraquat poisoning is higher than that from any other type of poisoning associated with agricultural chemicals ${ }^{7}$. The $\mathrm{LD}_{50}$ (oral) of paraquat for man is assumed to be $40 \mathrm{mg} / \mathrm{kg}^{8}$ ). In order to prevent accidental poisoning, emetics in 1979, blue azo dye in 1982 and specific odor substances in 1985 were added to paraquat preparations ${ }^{7)}$. Furthermore, the production of paraquat preparations of high concentration (24\%) was discontinued in July 1986 in Japan.

At present, no specific and effective antidote for paraquat poisoning is available. It was reported that the adsorption of paraquat in vitro onto activated carbon for the primary treatment of paraquat poisoning was more effective in normal saline solution ${ }^{9,10)}$. However, little work on the influence of the sodium chloride concentration on the adsorption capacity of activated carbon has been done so far . In this study, the influence of the sodium chloride concentration on the in vitro adsorption of paraquat onto activated carbon was investigated.

\section{Materials and Methods}

The paraquat used as an adsorbate was a commercial preparation (Gramoxone S, Nihon Nohyaku Co., Ltd.) and its concentration was indicated as $24 \%$. Activated carbon used as the adsorbent was Shirasagi G2C (Takeda Chemical Ind., Ltd.). The sodium chloride was of extra pure reagent grade (Nakarai Tesque Inc.).

Adsorption isotherms were obtained as follows. A weighed amount of activated carbon, $0.2 \sim 0.5 \mathrm{~g}$, was shaken with $50 \mathrm{ml}$ of paraquat solution of $c a .200 \sim 3500 \mathrm{mg} / \mathrm{L}$ for $24 \mathrm{hrs}$ at $37^{\circ} \mathrm{C}$. After filtration, the paraquat concentration in the filtrate was measured by a colorimetric method using an alkaline sodium dithionite solution ${ }^{11)}$. It took $24 \mathrm{hrs}$ or less to attain equilibrium adsorption.

The adsorption rate was measured in the paraquat-solution adsorbent system at $37^{\circ} \mathrm{C}$. Five grams of activated carbon was added to one liter of a stirred paraquat solution $(c a .800 \mathrm{mg} / \mathrm{L})$. Five milliliters of the suspension was sampled at regular intervals, and the paraquat concentrations were measured.

Ratios of sodium chloride addition to paraquat solution were $0.1,0.3,0.5,0.7$ and $0.9 \%$. 


\section{Results}

Addition of sodium chloride showed no effect on the absorbance at $600 \mathrm{~nm}$ as measured by colorimetric determination of the paraquat concentration.

Adsorption isotherms of paraquat at $37^{\circ} \mathrm{C}$ are shown in Figure 1. The amount of paraquat adsorbed increased with the increase in the amount of sodium chloride added. Table 1 indicates the amount of paraquat adsorbed at each equilibrium concentration. The amount adsorbed was calculated using the Freundlich equation as expressed by the following formula,

$\log \mathrm{V}=1 / \mathrm{n} \log \mathrm{C}+\log \mathrm{k}$

where $\mathrm{V}$ is the equilibrium amount adsorbed and $\mathrm{C}$ is the equilibrium concentration. Both $1 / \mathrm{n}$ and $\mathrm{k}$ are constants. Amounts adsorbed were increased by the addition of sodium chloride. At an equilibrium concentration of $1 \mathrm{mg} / \mathrm{L}$, the amount of paraquat adsorbed in $0.1 \%$ addition was about five times greater than that in sodium chloride-free solution. For other equilibrium concentrations, the amount of paraquat adsorbed also increased with the addition of sodium chloride.

The relationships between the amount of paraquat adsorbed at each equilibrium concentration and the concentration of sodium chloride in solution are shown in Figure 2. The amount adsorbed was approximately proportional to the concentration of sodium chloride in solution. It was recognized that the addition of sodium chloride increased the amount of paraquat adsorbed onto the activated carbon.

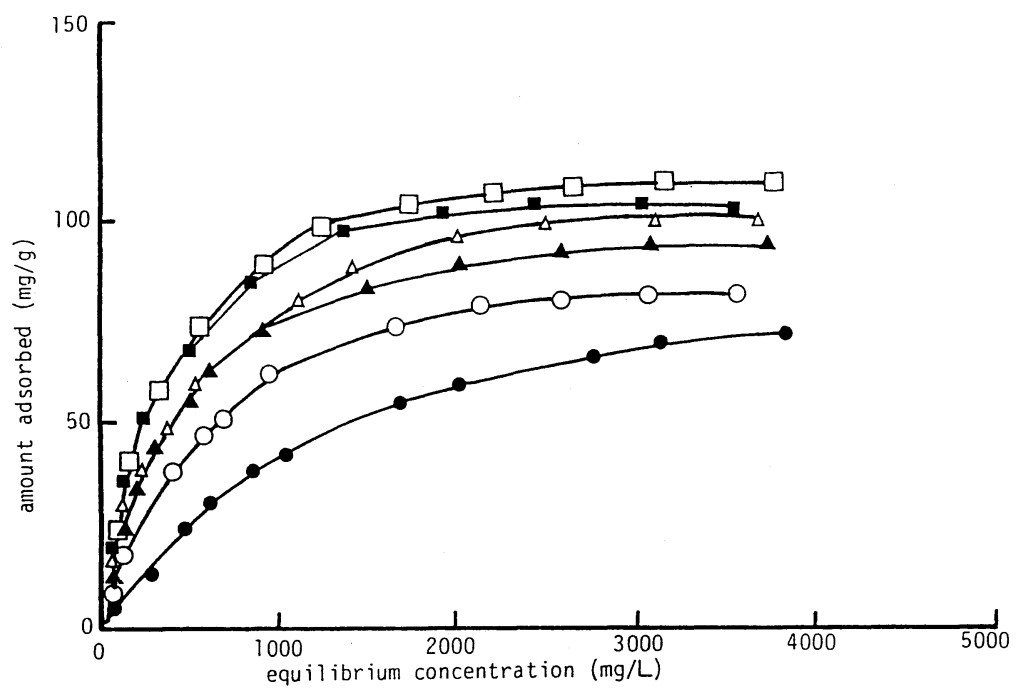

Fig. 1 Adsorption Isotherm of Paraquat at $37^{\circ} \mathrm{C}$

$\mathrm{NaCl}(\%): \bigcirc: 0, \bigcirc: 0.1, \mathbf{\Delta}: 0.3, \triangle: 0.5, \boldsymbol{\square}: 0.7, \square: 0.9$

Table 1 Equilibrium Amount of Paraquat Adsorbed

\begin{tabular}{lcccc}
\hline & \multicolumn{4}{c}{ Amount Adsorbed $(\mathrm{mg} / \mathrm{g})$} \\
\cline { 2 - 5 } $\begin{array}{c}\mathrm{NaCl} \\
(\%)\end{array}$ & $\begin{array}{c}\mathrm{v} \text { at } \\
1 \mathrm{mg} / \mathrm{L}\end{array}$ & $\begin{array}{c}\mathrm{v} \text { at } \\
10 \mathrm{mg} / \mathrm{L}\end{array}$ & $\begin{array}{c}\mathrm{v} \text { at } \\
100 \mathrm{mg} / \mathrm{L}\end{array}$ & $\begin{array}{c}\mathrm{v} \text { at } \\
1000 \mathrm{mg} / \mathrm{L}\end{array}$ \\
\hline 0 & 1.55 & 4.63 & 13.86 & 41.45 \\
0.1 & 7.73 & 15.31 & 30.29 & 59.95 \\
0.3 & 8.95 & 17.82 & 35.51 & 70.75 \\
0.5 & 9.08 & 18.37 & 37.17 & 75.23 \\
0.7 & 11.21 & 21.66 & 41.86 & 80.90 \\
0.9 & 9.42 & 19.42 & 41.37 & 86.71 \\
\hline
\end{tabular}


The amount of activated carbon needed for $90 \%$ removal of paraquat is indicated in Table 2 . The amount of activated carbon was calculated according to the method of Ogino $e a^{11)}$. The equation can be expressed in the following form:

$$
\mathrm{M}=\left[\mathrm{C}_{1}-\mathrm{C}_{2}\right] / \mathrm{V}
$$

where $\mathrm{M}$ is the amount of activated carbon needed for $90 \%$ removal, $\mathrm{C}_{1}$ is the initial concentration, $\mathrm{C}_{2}$ is the one-tenth concentration of $\mathrm{C}_{1}$, and $\mathrm{V}$ is the amount adsorbed at $\mathrm{C}_{2}$. The amount needed for $90 \%$ removal in the initial paraquat concentration of $1000 \mathrm{mg} / \mathrm{L}$ was the largest in the sodium chloride-free solution and smallest in the solution with $0.7 \%$ addition of sodium chloride. The difference in the amount of activated carbon needed for $90 \%$ removal between the sodium chloride-free case and the case with 0.7 or $0.9 \%$ addition of sodium chloride was three times or more with an initial paraquat concentration of $1000 \mathrm{mg} / \mathrm{L}$. The difference with an initial concentration of $10 \mathrm{mg} / \mathrm{L}$ was about $5-7$ times .

In the evaluation of adsorbent, the adsorption rate is another factor to be determined. In Figure 3 , the time course of the paraquat adsorption is shown. The addition of sodium chloride accelerated the adsorption rate of paraquat onto activated carbon.
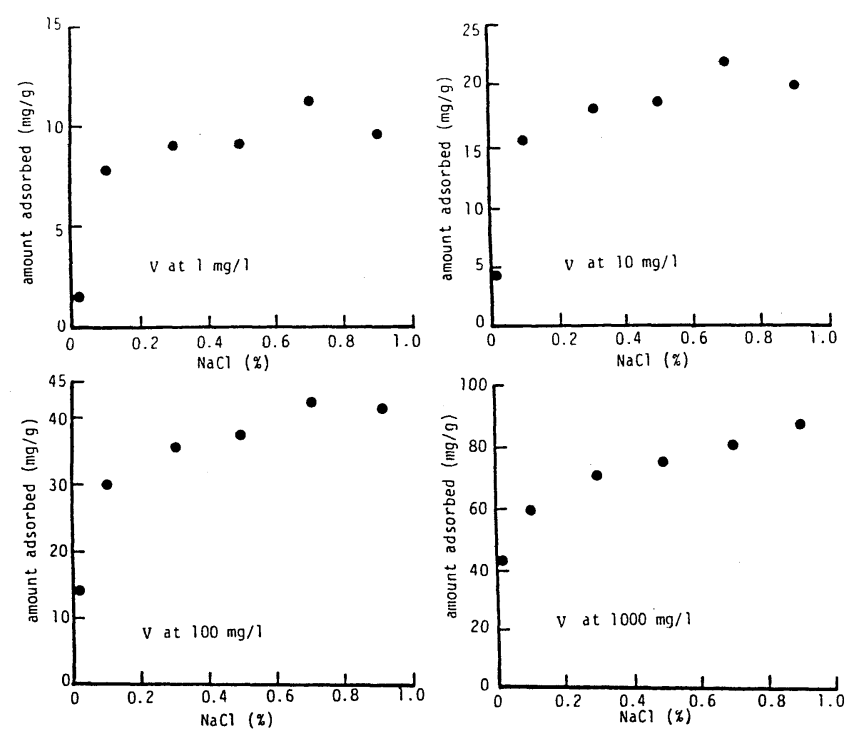

Fig. 2 Relationships between the Amount of Paraquat Adsorbed and the Concentration of Sodium Chloride

Table 2 Amount of Activated Carbon needed for $90 \%$ Removal of Paraquat at Various Initial Concentrations

\begin{tabular}{lccc}
\hline \multirow{2}{*}{$\begin{array}{c}\mathrm{NaCl} \\
(\%)\end{array}$} & \multicolumn{3}{c}{ Amount of } \\
\cline { 2 - 4 } & $1000 \mathrm{mg} / \mathrm{L}$ & $100 \mathrm{mg} / \mathrm{L}$ & $10 \mathrm{mg} / \mathrm{L}$ \\
\hline 0 & 64.9 & 19.4 & 5.8 \\
0.1 & 29.7 & 5.9 & 1.2 \\
0.3 & 25.3 & 5.1 & 1.0 \\
0.5 & 24.2 & 4.9 & 1.0 \\
0.7 & 21.5 & 4.2 & 0.8 \\
0.9 & 21.8 & 4.6 & 1.0 \\
\hline
\end{tabular}




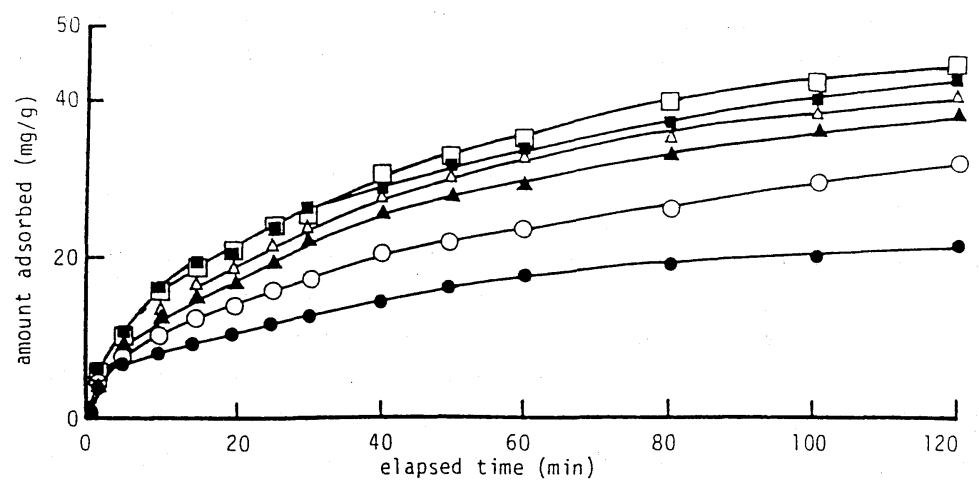

Fig. 3 Time Courses of Paraquat Adsorption in Various Concentration of NaCl $\mathrm{NaCl}(\%): \bigcirc: 0, \bigcirc: 0.1, \boldsymbol{\Delta}: 0.3, \triangle: 0.5, \square: 0.7, \square: 0.9$.

\section{Discussion}

Activated carbon has been used for the primary treatment of drug poisoning ${ }^{3,4)}$. The efficacies of activated carbon, natural aluminum silicate, bentonite, and a cation exchange resin for paraquat poisoning have been reported ${ }^{13 \sim 16}$. In recent years, the high removal capacities of kayexalate and kalimate, which are medical resins for the treatment of hyperkalemia, for paraquat have been reported ${ }^{17,18)}$. Although the removal capacity of activated carbon for paraquat is inferior to that of medical resin, activated carbon has been evaluated as a safe and effective gastrointestinal adsorbent. For paraquat removal by activated carbon, the following methods are proposed as a means of improving the adsorption capacity; the screening of a suitable activated carbon or surface modification of activated carbon by plasma irradiation, wet oxidation, and the choice of a suitable solvent in preparation of the carbon suspension. We have previously reported that the amount of paraquat adsorbed was large in normal saline solution ${ }^{9,10)}$. In this paper, we discussed the change in the amount of paraquat adsorbed by activated carbon in solutions with different sodium chloride concentrations.

The enhancing effect of saline purgatives on the in vitro adsorption of drugs by activated carbon has been reported. Ryan et $\mathrm{l}^{19}{ }^{19}$ reported the effect of magnesium citrate on the ability of activated carbon to adsorb sodium salicylate. They found that more salicylate was adsorbed onto activated carbon in the presence of magnesium citrate than in water alone. They did not report the mechanism of the enhanced adsorption of salicylate onto activated carbon in the presence of magnesium citrate, but the effects of $\mathrm{pH}$ and ionic strength have been excluded. Lapierre et al $^{20)}$ also reported that magnesium citrate actually enhanced the ability of activated carbon to adsorb aspirin in a simulated intestinal solution. They thought the mechanism of enhanced adsorption of aspirin was due to a $\mathrm{pH}$ change in the simulated intestinal solution brought about by the addition of magnesium citrate, thus resulting in less ionized salicylate and enhanced binding.

In our experiments, the adsorption capacity of activated carbon was observed to be enhanced by the addition of sodium chloride. We assumed that the reason for the increased adsorption capacity for paraquat by activated cabon in the presence of sodium chloride was as follows. The dissociation of paraquat in solution was inhibited by the addition of sodium chloride, that is, the phenomenon of salting out occurred in solution. Therefore, paraquat was adsorbed more abundantly onto the activated carbon.

It was concluded that the addition of sodium chloride to a carbon suspension was effective to promote adsorption removal of paraquat. 


\section{Summary}

The enhancing effect of sodium chloride addition on the adsorption of paraquat onto activated carbon was discussed from the standpoints of equilibrium amoumt adsorbed and adsorption rate $i n$ vitro.

The amount of paraquat adsorbed was increased by the addition of sodium chloride. The amount adsorbed with $0.1 \%$ addition was about five times greater than that in sodium chloride-free solution at an equilibrium concentration of $1 \mathrm{mg} / \mathrm{L}$. The adsorption rate of paraquat onto activated carbon was also accelerated by sodium chloride addition. Kinetic constants in $0.1 \%$ and $0.9 \%$ sodium chloride solution were about 1.4 and 2.0 times greater, respectively, than that in sodium chloride-free solution.

It was confirmed that paraquat removal by activated carbon was enhanced by sodium chloride addition. The reason was assumed to be the interrupted dissociation of paraquat in solution caused by sodium chloride addition.

\section{References}

1) Donovan, J.W. : Activated charcoal in management of poisoning. A revitalized antidote, Postgrad. Med. , 82, 52-59 (1987).

2 ) Greensher, J., Mofenson, H.C. and Caraccio, T.R.: Ascendency of the black bottle (activated charcoal), Pediatrics, 80, 949-951 (1987).

3 ) Javaid, K.A. and El-Mabrouk, B.H. : In vitro adsorption of phenobarbital onto activated charcoal, J. Pharm. Sci. , 72, 82-85 (1983).

4 ) Neuvonen, P.J., Kannisto, H. and Hirvisalo, E.L.: Effect of activated charcoal on absorption of tolbutamide and valproate in man, Eur. J. Clin. Pharmacol., 24, 243-246 (1983).

5 ) Swan, A.A.B. : Exposure of spray operators to paraquat, Brit. J. Industr. Med., 26, 322-329 (1969).

6 ) Howard, J.K.: Paraquat, a review of worker exposure in normal usage, J. Soc. Occup. Med., 30, 6-11 (1980).

7 ) Ukai, S. and Kawase, S. : Paraquat poisoning and forensic chemistry, Jpn. J. Toxicol. Environ. Health, 31, 283-297 (1985). (in Japanese)

8 ) Natori, H. : Paraquat poisoning, Jpn. J. Acute Med., 3, 1317-1325 (1979). (in Japanese)

9 ) Nakamura, M., Tanada, S., Nakamura, T., Keshi, H. and Kawanishi, T.: In vitro adsorption characteristics of paraquat by granular activated carbon, Chem. Express, 4, 357-360 (1989) .

10) Kitakouji, M. , Miyoshi, T., Tanada, S. and Nakamura, T. : In vitro adsorption removal of paraquat by activated carbon and cation exchange resin, Bull. Environ. Contam. Toxicol. , 42, 926-930 (1989).

11) Calderbank, A. and Yuen, S.H.: An ion-exchange method for determining paraquat residues in food crops, Analyst, 90, 99-106 (1965).

12) Ogino, K., Aibara, K., Otsuka, M. and Takahashi, H.: Adsorptivities of water-soluble fatty acids on surface-modified active carbon in aqueous solution, J. Jpn. Oil Chem. Soc., 28, 611-618 (1979). (in Japanese)

13) Okonek, S., Weilemann, L.S., Majdanzic, J., Setyadharma, H., Reinecke, H.J., Baldamus, C.A., Lohmann, J., Bonzel, K.E. and Thon, T. : Successful treatment of paraquat poisoning: activated charcoal per os and "continuous hemoperf usion", J. Toxicol. Clin. Toxicol. , 19, 807-819 (1982-83).

14) Kawai, M., Koyama, M., Kaneko, Y. and Ogasawara, S. : Efficacy of the use of adsorbent in the treatment of paraquat poisoning of dog, J. Jpn. Assoc. Rural Med., 30, 791-802 (1981). (in Japanese)

15) Smith, L.L., Wright, A., Wyatt, I. and Rose, M.S. : Effective treatment for paraquat poisoning in rats and its relevance to the treatment of paraquat poisoning in man, Brit. Med. J. , 4, 569-571 (1974). 
16) Staiff, D.C. , Irle, G.K. and Felsenstein, W.C. : Screening of various adsorbents for protection against paraquat poisoning, Bull. Environ. Contam. Toxicol., 10, 193-199 (1973).

17) Nokata, M., Tanaka, T., Tsuchiya, K. and Yamashita, M.: Alleviation of paraquat toxicity by kayexalate and kalimate in rats, Acta Pharmacol. Toxicol. , 55, 158-160 (1984).

18) Yamashita, M., Naito, H. and Takagi, S.: The effectiveness of a cation resin (kayexalate) as an adsorbent of paraquat, experimental and clinical studies, Hum. Toxicol. , 6, 89-90 (1987).

19) Ryan, C.F., Spigiel, R.W. and Zeldes, G.: Enhanced adsorption capacity of activated charcoal in the presence of magnesium citrate, Clin. Toxicol., 17, 457-461 (1980).

20) Lapierre, G., Algozzine, G. and Doering, P. L. : Effect of magnesium citrate on the in vitro adsorption of aspirin by activated charcoal, Clin. Toxicol., 18, 793-796 (1981) .

\section{活性炭へのパラコート吸着における塩化ナトリウムの促進効果}

$$
\begin{aligned}
& \text { 棚田成 紀*1, 中 村 武夫*1, 馬 小 紅*1, } \\
& \text { 樋 口 俊 一*1, 三 好 保*2, 田 村 隆 教*2, } \\
& \text { 今 木 雅 英*2 }
\end{aligned}
$$

\footnotetext{
活性炭によるパラコート除去における塩化ナトリウムの促進効果について, 吸着量および吸着速度の観点より考察し た。

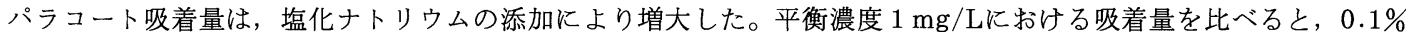
の塩化ナトリウム添加で, 無添加の場合より, 約 5 倍高值を示した。

活性炭に対するパコートの吸着速度においても，塩化ナトリウムの添加により促進効果を認めた。 $0.1 \%$ おび $0.9 \%$ の塩化ナトリウム添加における速度定数は，無添加の場合より約1.4倍および 2 倍高值を示した。

活性炭によるパラコート除去において，塩化ナトリウム添加による促進効果が認められた。塩化ナトリウム添加によ り，溶液中のパラコートの解離が妨げられることによるものであると推察した。
}

Key words : Paraquat removal, Activated carbon, Addition of sodium chloride, Enhancing effect パラコート除去, 活性炭, 塩化ナトリウム添加, 促進効果 